\title{
Waves of Mental Health Demands During the COVID-19 Pandemic
}

Eduardo Jorge Sant'Ana Honorato", "*; André Luiz Machado das Neves*; Munique Therense Costa de Morais Pontes*; Gizelly de Carvalho Martins"; Vivian Silva Lima Marangoni" ${ }^{*, *}$; Sonia Maria Lemos*

\author{
*School of Health Sciences , Amazonas State University (UEA), Manaus, Brazil \\ ${ }^{*}$ Manaus Municipal Health Secretariat( SEMSA), Manaus, Brazil
}

Corresponding author: Prof. Dr. Eduardo J. S. Honorato: School of Health Sciences, Manaus, AM, Brazil. E-mail: ehonorato@uea.edu.br / eduhonorato@hotmail.com

\begin{abstract}
:
This work presents a compilation of data obtained by clinical psychologists during the Covid19 pandemic in Brazil. Through searches on social media with \#Covid19 and \#MentalHealth and the exchange of information on networks of professionals, it was possible to compile and group the main psychological symptoms presented during isolation. Information was clustered according to the period it appeared, in order to guide future situations. Moreover, to prepare a group of clinical psychologists to provide online assistance.
\end{abstract}

Keywords: COVID-19; Mental Health; Psychological Symptoms

\section{Introduction}

The declaration of COVID-19 Pandemic by the World Health Organization on March 11,2020 , brought several impacts for all countries on the planet. In addition to economic and political issues, it also brought social, emotional, and behavioral impacts.

As the world prepared itself by closing borders, airports, isolating populations, and all other public health decisions, the waves of mental health demands started progressively. Beginning in China and later spreading to Europe, especially Italy and Spain until it got to the USA, Brazil and other countries in America, we perceived different phases of psychological demands, whether it was to the mental health services by phone or the online modality, adopted by most mental health professionals in the world.

We built this article on a multi-site approach and on multiple time frames ${ }^{1}$. It articulates the perception of psychologists who are working in actions to confront COVID-19, through remote activities in Brazil and experiences shared by coworkers from other countries via social media.

We used the hashtags \#Covid19 and \#Mental Health to search on social networks. Through them, we created a network of contacts with professionals from other countries who shared articles and reports of interventions. The most recent articles, published or in pre-print were shared among professionals. Through these articles, this one was built as a narrative review. Following the movement of discourses and disconnected actors ${ }^{2}$ - such as the sharing of actions by professionals from countries with different socio-economic and political specificities, in the public responses to coping with COVID-19 - we sough to demonstrate how the demands on the services offered were in Brazil, one of the likely epicenters of the disease in the coming weeks. These connections between experiences with other countries demonstrated how networks are formed, based on the relationships between their elements by bringing together different places and times within a frame of reference, which in this study was called Waves of Mental Health Demands.

\section{Waves of Mental Health Demands}

With the pandemic moving in waves around the planet, spreading geographically, it was possible to verify not only its progress from the topographical point of view but also based on the emotional impacts reported. First, China and some Asian countries, such as 
Thailand, Japan, and South Korea, until it reached the United States and France, still in January 2020. The first major impact, after China, was in Italy ${ }^{3}$, which had their first case on January 30,2020 , but the first death was already in February. With the alarming scenario in Italy, most of the countries began to adopt more drastic measures, such as total isolation (lockdown) and border closure.

We named Waves of Mental Health Demands according to the situation in which each country was, not obeying the chronological order of contagion, since these psychological aspects are directly linked to the public health decisions made by its political leaders. We expect it might help to prevent some consequences of the Covid-19 pandemic ${ }^{4}$.

China reported experiences using online care ${ }^{5}$, and then Italy ${ }^{6}$ and France $^{7}$ used the same technologies and were followed by other countries. It helped to avoid any unnecessary exposure to the virus ${ }^{8}$.

\section{1st Wave - Pre-Pandemic and the Beginning - Anxiety and Depression}

As soon as the population is informed by the local news that the virus has already reached the local cities, first symptoms described by patients and researchers are:

- Increase of anxiety levels9 10111213141516171819202122 including children'19 2324

- Depression 121314161825 26, including children 2324

- Fear of contagion12 14192728

- Fear of losing a job14 2728

- Social risks and consequences 29

- Fear of death25.

- Loneliness / social isolation 1216171830

- Increase the use of alcohol and drugs, including relapse 163132

- Insomnia 12163334

- Easily annoyed or irritable ${ }^{13}$

- Fear of going back to work ${ }^{35}$

- Lack or excess of information ${ }^{33}$

- Fear of shortage resources (treatment, drugs or tests) ${ }^{33}$

- Maternity/Pregnancy during Covid-19 Pandemic ${ }^{36}$

Fear seems to be the most present feeling in this period ${ }^{10} 1937$, mainly due to the dissemination of information that has not been scientifically validated. We learned from Italy's experience that it is necessary to concentrate information and pass it on to the public ${ }^{38}$ as well as monitoring social media ${ }^{39}$ as it can be dangerous spreading fake News or panic ${ }^{40}$, causing what is called infodemic ${ }^{41}$.

Those who already had a mental disorder, such as $O C D^{42}$, may experience an increase in symptoms ${ }^{14} 1727334344$. It also includes children and adolescents ${ }^{45}$. Others start to experience the first symptoms and seek help. At this moment, the use of cyberculture resources applied to public health ${ }^{45}{ }^{46}$ was fundamental, especially in teleconsultations and also communications for patients, relatives, and care workers 4748 .

It is important to note that the concept of "normality" starts to change since it is common during this period to show mood swings, affective lability, irritability. The psychological assistance in this period becomes essential routine guidance, exercises to control anxiety, control the exposure to the media, and tools to deal with new routines ${ }^{11} 49$.

In some countries, many adopted the home office model of working, and the number of marital and family conflicts start to increase. The number of reports of domestic violence ${ }^{16}$ rise as aggressive behavior ${ }^{12}$ shows as a symptom. The increase in domestic violence is not due to the pandemic itself but to the worsening of marital tensions that already existed before the pandemic context and the distancing of women from their support and protection network, emphasizing the condition of risk ${ }^{50}$.

Some countries anticipated this information through social media reports from various Chinese professionals and newspaper articles and were more attentive in developing possible ways of fighting it. We knew the first wave was coming as the panic had been reported in China ${ }^{51} 52$.

In countries where schools were closed, many parents began to complain about school demands, either due to lack of preparation or lack of skills to deal with the homeschooling model. 


\section{2nd Wave - During the Pandemic}

During the pandemic, when the deaths begin, the symptoms of the first wave are accentuated. The demands are still related to the early symptoms, but with indications of emotional fatigue, given the prolongation of isolation. It does not matter if it was vertical, social, or total isolation (lockdown). Some new complaints are:

- Financial loss 1733

- Domestic violence 161753

- Marital problems

- Emotional isolation ${ }^{33}$

- Boredom ${ }^{16} 33$

- Stigma ${ }^{16} 18335455$

- Difficulties dealing with homeschooling 24

The different generations that co-habit today have not had experiences with isolation ${ }^{30}$, except for countries that have been involved in international or internal wars. The habit of staying at home, isolated, was something not experienced by millions of people worldwide. Parallel to the feelings of the first wave, the symptoms of fear of contagion ${ }^{27}{ }^{28}$, fear of death, and considerations about the uncertain future begin to accentuate since many lost their jobs ${ }^{27}$.

Not all countries have implemented social and financial benefit policies to support this period. And even those who have implemented it, the uncertainty of the future, the labor market and the economic situation begins to take over the population.

Another critical point is also the care for the health professionals ${ }^{20}{ }^{56}$, many of whom are emotionally exhausted ${ }^{14} 17$, and started to use the mental health services provided and describe other symptoms:

- Burnout syndrome or high level of stress ${ }^{16} 182257585960$

- Suffering from the absence and separation from their family members, and many of whom are afraid of dying 61

- Fear the contamination. ${ }^{12} 1619586162$

- Loss of colleagues 62

- Substance abuse ${ }^{34}$

- Sleeping problems ${ }^{63}$

People undergoing home treatment for Covid-19 start to seek help to deal with their fear of death and isolation ${ }^{29}$, since they need to be totally separated from their loved ones, even in the same house. Those admitted to hospitals, with lighter conditions, also seek emotional refuge on social networks and online forms of care. It is common to find messages in social media from hospitalized people seeking to satisfy their affection and social demands ${ }^{64}$. We should pay attention to those, providing psychological support ${ }^{12} 1316$.

Parents begin to report domestic difficulties, due to the anxiety or irritability of minors. Parents of teenagers and young adults might face consequences of the excessive use of videogames. 665

As the pandemic advances and the number of deaths increases, the number of people seeking psychological help to deal with the grief $6{ }^{16}$ rise too. The deads are no longer numbers and statistics, but they have a first and last name, as well as an affective bond. It is no longer 100 deaths per day, but a brother, a cousin, or even a husband, father, or mother. The professionals then begin to deal with the demands of elaborating mourning, since the ritual of watching over the body and burial is restricted by health rules, modified in several countries. People suffer at home mourning the impossibility of providing the proper ceremonies. The same happened during the 1918 influenza pandemic ${ }^{47}$.

Important note: Between the first and the second wave, the number of suicides'12 16272640 among the general population increases and also suicide ideation ${ }^{14} 2666$. Either by the fear of the unknown in the first phase, or by the losses and suffering faced in the second. This phenomenon is present since the middle of the first wave and extends throughout the process $^{67} 6869$. It was already reported cases among health workers ${ }^{62}$. Patients who had Covid-19 also should be monitored. ${ }^{70}$ 


\section{3rd Wave - After the Pandemic}

It is still quite recent, and without much data from experience reports, this third wave has a very theoretical emphasis. It starts once life returns to normal, with some adjustment. China entered this period, with the relaxation of social isolation and the return to normal activities. Some European countries and American States also gradually started to relax their quarantines, and life tends to return to normal (the new normal). We will only know the real impacts when all countries leave the period of isolation, and we will have a real scenario ${ }^{71}$.

It is worth noting that there is an expectation that the standards of normality will be reformulated in-depth in the post-pandemic context. Social scientists believe that the pandemic experience forced people to return to fatality, which weakens individual promises for the future and strengthens attitudes of shared care. Despite the suffering arising from the fragmentation of personal fantasies, such a scenario can favor the recognition of social inequalities and the promotion of citizenship and rights ${ }^{72}$.

What we can take from previous experiences, which are related to wars and another pandemic period, there will be an increase in the number of cases of anxiety disorder, especially post-traumatic stress disorder(PTSD)18 203533 54. Children and adolescents may also experience mixed anxiety and depression ${ }^{23}$. The health workers ${ }^{10} 6173$, due to the higher demand, will suffer from depression, anxiety and burnout syndrome. They will require special attention.

We can use as an example the experience of Sierra Leone ${ }^{74}$ that after the Ebola pandemic needed to create strategies for mental health ${ }^{75}$ or other experiences from natural disasters ${ }^{76}{ }^{77}$. Always having in mind the SARS-CoV in 2002 was referred as "mental health catastrophe"12 and we must be prepared for what is coming.

\section{Final Considerations}

Based on individual experiences from these periods, traumas will arise and will demand much attention from mental health professionals. It will be necessary to review all classical techniques to resolve conflicts of this type.

More and more mental health professionals will be demanded. While politicians and economists will be concerned about reorganizing countries' economies, mental health professionals will have to increase their workload and demand because, in exceptional situations like this, it is tough for someone to come out unscathed.

We know that these are not, by far, all the symptoms that appear in this period, and much more will be added to this scenario.

However, paradoxically, the scenario of evidence of human finitude can potentiate the construction of meanings of valuing life. The torpor caused by the anguish of the possibility of death (re) invents mental health needs that, at its core, denote desires to live.

\section{Author Roles}

EJSH and SML developed key article concepts. EJSH led the writing of the manuscript. ALMN, MTCMP, GCM, and VSLM assisted with writing areas of the manuscript related to their expertise and revised the manuscript for intellectual content. All authors reviewed the final manuscript before submitting it for publication.

\section{Financial disclosures}

None.

\section{Declaration of Competing Interest}

None of the authors report any conflict of interest.

\section{Acknowledgments}

None.

1. Ferreira VK. Resenha 2: Fora de contexto - Marilyn Strathern. Horizontes Antropol. 2015;21(43):395-399. http://www.scopus.com/inward/record.url?eid=2-s2.084940862865\&partnerID=tZOtx3y1.

2. Segata J. LATOUR, Bruno. Reagregando o Social: uma introdução à Teoria do AtorRede. Ilha Rev Antropol. 2012;14(1,2):238-243. doi:10.5007/2175-8034.2012v14n1$2 \mathrm{p} 238$ 
3. D'Agostino A, Demartini B, Cavallotti S, Gambini O. Mental health services in Italy during the COVID-19 outbreak. The Lancet Psychiatry. 2020;7(5):385-387.

doi:10.1016/S2215-0366(20)30133-4

4. Roycroft M, Wilkes D, Fleming S, Pattani S, Olsson-Brown A. Preventing psychological injury during the covid-19 pandemic. BMJ. 2020;369(May):m1702. doi:10.1136/bmj.m1702

5. Liu S, Yang L, Zhang C, et al. Correspondence Online mental health services in China during the COVID-19 outbreak. The Lancet Psychiatry. 2020;0366(20):2019-2020. doi:10.1016/S2215-0366(20)30077-8

6. Sani G, Janiri D, Di Nicola M, Janiri L, Ferretti S, Chieffo D. Mental health during and after the COVID-19 emergency in Italy. Psychiatry Clin Neurosci. 2020:5-6. doi:10.1111/pcn.13004

7. Corruble E. A Viewpoint From Paris on the COVID-19 Pandemic: A Necessary Turn to Telepsychiatry. J Clin Psychiatry. 2020;81(3). doi:10.4088/JCP.20com13361

8. Yao H, Chen JH, Xu YF. Rethinking online mental health services in China during the COVID-19 epidemic. Asian J Psychiatr. 2020;50(March):102015. doi:10.1016/j.ajp.2020.102015

9. Walter-McCabe HA. Coronavirus Pandemic Calls for an Immediate Social Work Response. Soc Work Public Health. 2020;35(3):69-72. doi:10.1080/19371918.2020.1751533

10. Rana W, Mukhtar S, Mukhtar S. Mental health of medical workers in Pakistan during the pandemic COVID- 19 outbreak. Asian J Psychiatr. 2020;51:102080. doi:10.1016/j.ajp.2020.102080

11. Banerjee D. I P re of. Asian J Psychiatr. 2020:102014. doi:10.1016/j.ajp.2020.102014

12. Zheng W. Mental health and a novel coronavirus (2019-nCoV) in China. J Affect Disord. 2020;269:201-202. doi:10.1016/j.jad.2020.03.041

13. Zhang J, $\mathrm{Lu} \mathrm{H}$, Zeng $\mathrm{H}$, et al. The differential psychological distress of populations affected by the COVID-19 pandemic. Brain Behav Immun. 2020;(April):1-2. doi:10.1016/j.bbi.2020.04.031

14. Thakur V, Jain A. COVID 2019-suicides: A global psychological pandemic. Brain Behav Immun. 2020;(xxxx). doi:10.1016/j.bbi.2020.04.062

15. Khan S, Siddique R, Li H, et al. Impact of coronavirus outbreak on psychological health. J Glob Health. 2020;10(1):1-6. doi:10.7189/jogh.10.010331

16. Kumar A, Nayar KR. COVID 19 and its mental health consequences. J Ment Heal. 2020;8237:1-2. doi:10.1080/09638237.2020.1757052

17. Choi KR, Heilemann M V, Fauer A, Mead M. A Second Pandemic: Mental Health Spillover From the Novel Coronavirus (COVID-19). J Am Psychiatr Nurses Assoc. 2020:1078390320919803. doi:10.1177/1078390320919803

18. Health P, Fakult M, Fakult M, et al. Psychosoziale Folgen von Quarantänemaßnahmen bei schwerwiegenden Coronavirus-Ausbrüchen : ein Rapid Review Psychosocial Impact of Quarantine Measures During Serious Coronavirus Outbreaks : A Rapid Review. 2020:179-189.

19. Tsamakis K, Rizos E, Manolis A, et al. [Comment] COVID-19 pandemic and its impact on mental health of healthcare professionals. Exp Ther Med. 2020:3451-3453. doi:10.3892/etm.2020.8646

20. Garcovich S, Bersani F., Chiricozzi A, De Simone C. Mass quarantine measures in the time of COVID-19 pandemic: psycho-social implications for chronic skin conditions and a call for qualitative studies. J Eur Acad Dermatology Venereol. 2020:0-2. doi:10.1111/jdv.16535

21. Park S-C, Park YC. Secondary Emotional Reactions to the COVID-19 Outbreak Should be Identified and Treated in Korea. J Korean Med Sci. 2020;35(17):17-19. doi:10.3346/jkms.2020.35.e161

22. Yao $\mathrm{H}$, Chen $\mathrm{J}-\mathrm{H}$, Zhao $\mathrm{M}$, et al. Mitigating mental health consequences during the COVID-19 outbreak: Lessons from China. Psychiatry Clin Neurosci. 2020. doi:10.1111/pcn.13018

23. Xie X, Xue Q, Zhou Y, et al. Mental Health Status Among Children in Home Confinement During the Coronavirus Disease 2019 Outbreak in Hubei Province, China. JAMA Pediatr. 2020;7:2-4. doi:10.1001/jamapediatrics.2020.1619

24. Lambrese J V. Helping children cope with the COVID-19 pandemic. Cleve Clin J Med. 2020:1-2. doi:10.3949/ccjm.87a.ccc010 
25. Zandifar A, Badrfam R. Iranian mental health during the COVID-19 epidemic. Asian J Psychiatr. 2020;51(February):101990. doi:10.1016/j.ajp.2020.101990

26. Mamun MA, Gri MD. First COVID-19 suicide case in Bangladesh due to fear of COVID-19 and xenophobia : Possible suicide prevention strategies. 2020;51(April):23. doi:10.1016/j.ajp.2020.102073

27. Kavoor AR, Chakravarthy K, John T. Remote consultations in the era of COVID-19 pandemic: Preliminary experience in a regional Australian public acute mental health care setting. Asian J Psychiatr. 2020;51:102074. doi:10.1016/j.ajp.2020.102074

28. Li I, Li Y, Li T, Alvarez-Napagao S, Garcia D. What are We Depressed about When We Talk about COVID19: Mental Health Analysis on Tweets Using Natural Language Processing. 2020. https://rnpprimo.hosted.exlibrisgroup.com/primo_library/libweb/action/display.do;jsessionid=DA8 F80BDD107CB33D1DA88A9B23FFAB5?tabs=detailsTab\&gathStatTab=true\&ct=displ ay\&fn=search\&doc $=T$ TN_proquest $2394445342 \&$ ind $x=1 \&$ reclds $=T N \_$proquest 23944453 42\&recldxs=0\&ele. Accessed May 6, 2020.

29. Li S, Wang Y, Xue J, Zhao N, Zhu T. The impact of covid-19 epidemic declaration on psychological consequences: A study on active weibo users. Int J Environ Res Public Health. 2020;17(6). doi:10.3390/ijerph17062032

30. Banerjee D, Rai M. Social isolation in Covid-19: The impact of loneliness. Int J Soc Psychiatry. 2020:20764020922269. doi:10.1177/0020764020922269

31. Da BL, Im GY, Schiano TD. COVID-19 Hangover: A Rising Tide of Alcohol Use Disorder and Alcohol-Associated Liver Disease. Hepatology. 2020:0-3. doi:10.1002/hep.31307

32. Rehm J, Kilian C, Ferreira-borges C, Jernigan D, Monteiro M, Parry CDH. Alcohol use in times of the COVID 19 : Implications for monitoring and policy. 2020;(March):1-4. doi:10.1111/dar.13074

33. Pfefferbaum B, North CS. Mental Health and the Covid-19 Pandemic. N Engl J Med. April 2020. doi:10.1056/nejmp2008017

34. Gold JA. Covid-19: adverse mental health outcomes for healthcare workers. BMJ. 2020;369(May):m1815. doi:10.1136/bmj.m1815

35. Tan W, Hao F, McIntyre RS, et al. Is returning to work during the COVID-19 pandemic stressful? A study on immediate mental health status and psychoneuroimmunity prevention measures of Chinese workforce. Brain Behav Immun. 2020. doi:10.1016/j.bbi.2020.04.055

36. Thapa SB, Mainali A, Schwank SE, Acharya G. Maternal mental health in the time of the COVID-19 pandemic. Acta Obstet Gynecol Scand. 2020:1-3. doi:10.1111/aogs.13894

37. Ren SY, Gao RD, Chen YL. Fear can be more harmful than the severe acute respiratory syndrome coronavirus 2 in controlling the corona virus disease 2019 epidemic. World J Clin Cases. 2020;8(4):652-657. doi:10.12998/wjcc.v8.i4.652

38. Antonelli G, Capobianchi MR, Riva E. The SARS-CoV-2 epidemic: how the Italian public is being informed. Clin Microbiol Infect. 2020;(xxxx):2-3. doi:10.1016/j.cmi.2020.03.037

39. Ni MY, Yang L, Leung CM, et al. Mental health, risk factors, and social media use during the COVID-19 epidemic and cordon sanitaire among the community and health professionals in Wuhan, China. JMIR public Heal Surveill. 2020. doi:10.2196/19009

40. Goyal K, Chauhan P, Chhikara K, Gupta P, Singh MP. Fear of COVID 2019 : First suicidal case in India ! Asian J Psychiatr. 2020;49(February):101989. doi:10.1016/j.ajp.2020.101989

41. Ahmad AR, Murad HR, R Gardner M. "The Impact of Social Media on Hyped Panic during the COVID-19 Pandemic: The Iraqi Kurdistan Case'"'." JMIR Ment Heal. 2020. doi:10.2196/19556

42. Kumar A, Somani A. Dealing with Corona virus anxiety and OCD. Asian J Psychiatr. 2020;51:102053. doi:10.1016/j.ajp.2020.102053

43. Fernández-Aranda F, Casas M, Claes L, et al. $<$ scp $>C O V I D</ s c p>-19$ and implications for eating disorders. Eur Eat Disord Rev. 2020;28(3):239-245. doi:10.1002/erv.2738

44. COVID-19 Global Pandemic: Implications for People With Schizophrenia and Related Disorders | Schizophrenia Bulletin | Oxford Academic. https://academic.oup.com/schizophreniabulletin/advance- 
article/doi/10.1093/schbul/sbaa051/5826166. Accessed May 9, 2020.

45. Golberstein E, Gonzales G, Meara E. How do economic downturns affect the mental health of children? Evidence from the National Health Interview Survey. Heal Econ (United Kingdom). 2019;28(8):955-970. doi:10.1002/hec.3885

46. Honorato EJSA. A interface entre saúde pública e cibercultura. Cienc e Saude Coletiva. 2014;19(2):481-485. doi:10.1590/1413-81232014192.21512012

47. Ingravallo F. Correspondence Death in the era of the. Lancet Public Heal. 2020;5(5):e258. doi:10.1016/S2468-2667(20)30079-7

48. Hu N, Pan S, Sun J, Wang Z, Mao H. Mental health treatment online during the COVID-19 outbreak. Eur Arch Psychiatry Clin Neurosci. 2020;(0123456789):19-20. doi:10.1007/s00406-020-01129-8

49. Garriga M, Agasi I, Fedida E, et al. The role of Mental Health Home Hospitalization Care during the COVID-19 pandemic. Acta Psychiatr Scand. 2020;2405:0-2. doi:10.1111/acps.13173

50. Vieira PR, Garcia LP, Maciel ELN. The increase in domestic violence during the social isolation: What does it reveals? Rev Bras Epidemiol. 2020;23:1-5. doi:10.1590/1980549720200033

51. Bao Y, Sun Y, Meng S, Shi J, Lu L. care to empower society. Lancet. 2020;6736(20):2019-2020. doi:10.1016/S0140-6736(20)30309-3

52. Xiang Y, Yang Y, Li W, et al. Comment Timely mental health care for the 2019 novel coronavirus outbreak is urgently needed. The Lancet Psychiatry. 2020;0366(20):20192020. doi:10.1016/S2215-0366(20)30046-8

53. Hatchimonji JS, Swendiman RA, Seamon MJ, Nance ML. Trauma does not quarantine: violence during the Covid-19 pandemic. Ann Surg. 2020:e-pub ahead of print. doi:10.1097/SLA.0000000000003996

54. Kisely S, Warren N, McMahon L, Dalais C, Henry I, Siskind D. Occurrence, prevention, and management of the psychological effects of emerging virus outbreaks on healthcare workers: rapid review and meta-analysis. BMJ. 2020;369:m1642. doi:10.1136/bmj.m1642

55. Budhwani H, Sun R. Referencing the novel coronavirus as the "Chinese virus" or "China virus" on Twitter: COVID-19 stigma (Preprint). J Med Internet Res. 2020;22:17. doi:10.2196/19301

56. Hu X, Huang W. Protecting the psychological well-being of healthcare providers affected by the COVID-19 outbreak: Implications for the psychological rescue work of international community. Nurs Health Sci. 2020;(2020):1-7. doi:10.1111/nhs.12727

57. Review ASC. COVID-19-Pandemie : Belastungen des medizinischen Personals Ein kurzer aktueller Review COVID-19 Pandemic : Stress Experience of Healthcare Workers. 2020:190-197.

58. Walton M, Murray E, Christian MD. Mental health care for medical staff and affiliated healthcare workers during the COVID-19 pandemic. Eur Hear J Acute Cardiovasc Care. 2020:204887262092279. doi:10.1177/2048872620922795

59. Working schedule, sleep quality and susceptibility to COVID-19 in healthcare workers. | Clin Infect Dis;2020 Apr 27. | MEDLINE.

https://pesquisa.bvsalud.org/controlecancer/resource/pt/mdl-32339218. Accessed May 9, 2020.

60. Galbraith N, Boyda D, McFeeters D, Hassan T. The mental health of doctors during the Covid-19 pandemic. BJPsych Bull. 2020:1-7. doi:10.1192/bjb.2020.44

61. Mohindra R, R R, Suri V, Bhalla A, Singh SM. Issues relevant to mental health promotion in frontline health care providers managing quarantined/isolated COVID19 patients. Asian J Psychiatr. 2020;51(March):102084. doi:10.1016/j.ajp.2020.102084

62. Zaka A, Shamloo SE, Fiorente P, Tafuri A. COVID-19 pandemic as a watershed moment: A call for systematic psychological health care for frontline medical staff. $J$ Health Psychol. 2020:1359105320925148. doi:10.1177/1359105320925148

63. Dong H, Zhang Q, Sun Z, Sang F, Xu Y. Sleep disturbances among Chinese clinical nurses in general hospitals and its influencing factors. BMC Psychiatry. 2017;17(1). doi:10.1186/s12888-017-1402-3

64. Zhang J, Wu W, Zhao X, Zhang W. Recommended psychological crisis intervention response to the 2019 novel coronavirus pneumonia outbreak in China : a model of West China Hospital. 2020;00(February):1-6. doi:10.1093/pcmedi/pbaa006

65. King DL, Delfabbro PH, Billieux J, Potenza MN. Problematic online gaming and the 
COVID-19 pandemic. J Behav Addict. 2020:2019-2021. doi:10.1556/2006.2020.00016

66. Karamouzian M, Johnson C, Kerr T. Public health messaging and harm reduction in the time of COVID-19. The Lancet Psychiatry. 2020;7(5):390-391. doi:10.1016/S22150366(20)30144-9

67. Wand APF, Zhong B-L, Chiu HFK, Draper B, De Leo D. Covid-19: The implications for suicide in older adults. Int psychogeriatrics. 2020;(May 2020):1-16. doi:10.1017/S1041610220000770

68. Brown S, Schuman DL. Suicide in the Time of COVID-19: A Perfect Storm. J Rural Health. 2020:1-8. doi:10.1111/jrh.12458

69. Kawohl W, Nordt C. COVID-19, unemployment, and suicide. The Lancet Psychiatry. 2020;7(5):389-390. doi:10.1016/S2215-0366(20)30141-3

70. Sher L. Are COVID-19 survivors at increased risk for suicide? Acta Neuropsychiatr. May 2020:1-4. doi:10.1017/neu.2020.21

71. Di Gennaro F, Pizzol D, Marotta C, et al. Coronavirus diseases (COVID-19) current status and future perspectives: A narrative review. Int $J$ Environ Res Public Health. 2020;17(8). doi:10.3390/ijerph17082690

72. Boletim n. $16 \mid$ As promessas de aprimoramento e o retorno à fatalidade. http://www.anpocs.com/index.php/ciencias-sociais/destaques/2328-boletim-n-16-aspromessas-de-aprimoramento-e-o-retorno-a-fatalidade. Accessed May 9, 2020.

73. Lai J, Ma S, Wang Y, et al. Factors Associated With Mental Health Outcomes Among Health Care Workers Exposed to Coronavirus Disease 2019. JAMA Netw open. 2020;3(3):e203976. doi:10.1001/jamanetworkopen.2020.3976

74. Leone S. Lessons from the field Mental health care during the Ebola virus disease outbreak in Sierra. 2017;(October):842-847.

75. Holmes EA, O'Connor RC, Perry VH, et al. Multidisciplinary research priorities for the COVID-19 pandemic: a call for action for mental health science. The Lancet Psychiatry. 2020;0366(20):1-14. doi:10.1016/S2215-0366(20)30168-1

76. County Y. Letter to the Editor Psychological distress of the 2019 super Typhoon Lekima among survivor-responders : A case study of Shanzao village, Yongjia County. 2020;50. doi:10.1016/j.ajp.2020.102033

77. Zhou Y, Liang Y, Tong H, Liu Z. Patterns of posttraumatic stress disorder and posttraumatic growth among women after an earthquake: A latent profile analysis. Asian J Psychiatr. 2019;(October):101834. doi:10.1016/j.ajp.2019.10.014 